\title{
Ficcionalização do testemunho em $A$ morte do inimigo, de Hans Keilson
}

\author{
[Fictionalizing the testimony in Der Tod des Widersachers, from Hans Keilson] \\ http://dx.doi.org/10.11606/1982-88372238168
}

Patricia Andrade ${ }^{1}$

\begin{abstract}
As we consider the literary works taken as part of the Literature of Testimony, we can observe the prevalence of autobiographical texts relating the atrocities of Nazi persecution and concentration camps. However, there are also many fictional texts, autobiographical or otherwise, that tell of such experiences and others related to the sufferings caused by National Socialism to a large part of the European population. Analysing Hans Keilson's Der Tod des Widersachers, we try to determine the signposts of fictionality that distance the novel from a possible autobiographical reading, and reflect on the ethical and aesthetic implications of Keilson's fictionalizing his own experiences.
\end{abstract}

Keywords: Hans Keilson; ficcionality; testimony.

Resumo: Ao considerarmos as obras que compõem a Literatura de Testemunho, podemos observar a prevalência de textos autobiográficos relatando as atrocidades da perseguição nazista e dos campos de concentração. No entanto, há também muitas obras ficcionais, de teor autobiográfico ou não, que narram tais experiências e outras relacionadas aos sofrimentos causados pelo nacional-socialismo a grandes parcelas da população europeia. Ao analisarmos a obra Der Tod des Widersachers, de Hans Keilson, procuramos determinar os índices de ficcionalidade que a afastam de uma possível leitura autobiográfica e refletir sobre as implicações éticas e estéticas de Keilson haver ficcionalizado experiências próprias.

Palavras-chave: Hans Keilson; ficcionalidade; testemunho.

\section{Gêneros da escrita sobre a Shoah}

Em meio à profícua literatura que surgiu e se disseminou a partir do Holocausto e sobre temas a ele tangentes, encontram-se numerosos textos de diferentes tratamentos quanto à questão da autoria: textos autobiográficos de sobreviventes, ficções de sobreviventes e ficções de autores sem experiência própria da catástrofe. Todos entretecem uma rede discursiva e um corpus que tem se consolidado, desde a literatura de resistência (ainda

\footnotetext{
${ }^{1}$ Department of Spanish and Portuguese, Brigham Young University, 3190B JFSB, Provo UT 84602-6702, Estados Unidos. E-mail: patriciabaialuna@gmail.com. ORCID: 0000-0002-8985-1068
}

(cc) BY-NC 
ANDRADE, P. - Ficcionalização do testemunho

durante as décadas de 1930 e 1940) até publicações recentes de testemunhas ou descendentes de vítimas do nazismo. Ao analisarmos o romance A morte do inimigo [Der Tod des Widersachers], de Hans Keilson, procuramos identificar os índices de ficcionalidade que mostram que, embora permeado de referências à realidade e de experiências possivelmente associadas à biografia de Keilson, o autor optou por elaborar uma obra ficcional. Buscamos, ainda, refletir sobre as consequências - estéticas e pragmáticas - de tal preferência e valorização do ficcional.

Inicialmente estabelecemos, portanto, a oposição fundamental em nossa leitura do romance: o ficcional divergindo do relato autobiográfico, e este último o consideramos nos moldes da escrita de Primo Levi, por exemplo, em que há o estabelecimento de um pacto autobiográfico. A partir deste pacto, o leitor já não questiona a todo tempo se determinadas passagens narradas realmente aconteceram ou não, mas toma-as por acontecimentos reais segundo o relato fiel - ainda que se considere a inexatidão da memória, pela qual se pauta tal relato - do narrador-autobiógrafo.

Para Philippe Lejeune (2014: 30), “o pacto autobiográfico é a afirmação, no texto, dessa identidade [autor-narrador-personagem], remetendo, em última instância, ao nome do autor, escrito na capa do livro". Tal afirmação pode estar presente desde o título, desenvolver-se no preâmbulo e ser confirmada ao longo do texto (ibidem: 37). Para ilustrar nosso exemplo, observamos que o prefácio de É isso um homem? afirma:

fui deportado para Auschwitz só em 1944. [...] A necessidade de contar "aos outros", de tornar "os outros" participantes, alcançou entre nós, antes e depois da libertação, caráter de impulso imediato e violento, até o ponto de competir com outras necessidades elementares. O livro foi escrito para satisfazer essa necessidade em primeiro lugar, portanto, com a finalidade de liberação interior. [...] Acho desnecessário acrescentar que nenhum dos episódios foi fruto de imaginação. (LEVI 1988: 7-8)

A última frase da citação acima expressa o intento de fazer uma "narração retrospectiva em prosa que uma pessoa real faz de sua própria existência, [focalizando] sua história individual” (LEJEUNE 2014: 16). Embora o nome do autor só apareça ao final na narrativa (ibidem: p. 169), menções ao próprio como “o italiano”, à sua formação como químico ou por seu número de prisioneiro, estão presentes em vários pontos do texto. Dessa forma, o leitor estabelece com a obra um pacto autobiográfico, considerando-a relato fiel da experiência de Primo Levi, sob sua própria perspectiva.

A obra de Hans Keilson, por sua vez, não estabelece tal pacto, primeiramente pela ausência do nome do narrador-personagem; além disso, vários outros aspectos textuais e pragmáticos aproximam a obra de um romance, como procuraremos demonstrar adiante. 
ANDRADE, P. - Ficcionalização do testemunho

Ao tratar do tema da ficcionalidade, deixamos de lado as vertentes panficcionalistas pós-modernas (RYAN 1980), que consideram haver algum nível de ficção em toda forma de escrita. Em primeiro lugar, estabelecemos o conceito de ficção aqui utilizado como toda forma de criação intencional, planejada e consciente por parte do autor, em virtude de alguma intencionalidade: esta pode ser a de literalmente criar, fantasiar ou apenas conferir maior poeticidade à narrativa. Está relacionada à elaboração literária que Bunia (2018) cunhou estetogenia, e de que Zipfel (2001: 20) destaca o aspecto estético (literarische Fiktion als ästhetische Fiktion). Portanto, não nos atemos à presença do elemento ficcional que preenche as lacunas da memória ou que se insere com a subjetividade do relator até mesmo em textos históricos. Baseamo-nos em um conceito pragmático de ficção como modalidade literária, com suas próprias convenções.

\section{Ficcionalidade: marcas textuais e questões pragmáticas}

Ao destacar a tensão entre o teor autobiográfico e a ficcionalidade na obra A morte do inimigo, desejamos apontar para os índices de ficcionalidade do romance e refletir sobre as consequências, ou possível intencionalidade do autor ao ficcionalizar tantas experiências reais de sua biografia. O campo da narratologia analisa o nível estrutural do texto e aponta para as marcas ali presentes que dão indícios do caráter fictício da história. Embora alguns considerem a ficção como modo de recepção de um texto (ZIPFEL 2001: 17), investigaremos nas páginas seguintes a aplicabilidade dos índices de ficcionalidade listados por Genette (1990) e definidos por Zipfel (2014: 103) como: “Als Fiktionssignale werden dann alle Werk-Informationen verstanden, mit Hilfe derer man im konkreten Fall die Entscheidung, einen Text als fiktional anzusehen, begründen kann". ${ }^{2}$

Há, entretanto, muitos elementos no texto que remetem a experiências sabidamente vividas por Keilson. Disso atesta Ulrike Weymann (2013: 74), em seu artigo "Erinnerung und Wirklichkeitsverlust in Der Tod des Widersachers", mostrando que a chave (ou pacto) para a leitura da obra não parece ser tão definitiva, em princípio. $\mathrm{O}$ narrador-protagonista de A morte do inimigo, que em nenhum momento é nomeado, é judeu, e foi durante sua infância que o nacional-socialismo chegou ao poder. Keilson compartilha essa mesma experiência: de origem judia, nascido em 1909, assistiu em sua

\footnotetext{
2 "Entende-se por sinal de ficção toda informação relativa à obra, com ajuda da qual pode-se justificar a leitura da mesma como texto ficcional". (Esta e demais traduções da autora).
} 
adolescência ao período pós-Primeira Guerra, à República de Weimar e a todos os problemas sociais e econômicos da época, que fomentaram o fortalecimento da extremadireita e a ascensão do nazismo.

O narrador-protagonista em dado momento da narrativa intradiegética (KEILSON 2013: 25) - pois, como veremos, há no romance dois níveis narrativos - se diz professor de Educação Física, outra característica em comum com Hans Keilson. Estudante de medicina em Berlin, este precisou interromper seus estudos por conta de sanções nazistas à instrução dos judeus; para se sustentar, Keilson trabalhou em escolas para judeus (como professor de Educação Física) e atuou também como músico durante sua juventude.

Assim como o Keilson da vida real, o narrador manteve-se por bastante tempo à margem de qualquer movimento de resistência ao nazismo. Somente anos mais tarde, já no exílio holandês, o autor tomou parte em atividades clandestinas de apoio aos refugiados e a crianças traumatizadas pela guerra, em virtude de sua especialização em psicanálise e, posteriormente, em psiquiatria.

Desconhecendo a biografia de Keilson, entretanto, ao leitor passariam despercebidas tais correspondências; A morte do inimigo é um romance com coerência interna, e o conhecimento dos vários aspectos da vida do autor que se encontram representados no romance lançam luz, para o pesquisador, sobre o procedimento de criação literária de Keilson, que ficcionalizou sua biografia.

Na página 73 do mesmo artigo de Weymann, lemos a seguinte citação, em que Keilson comenta a relação entre sua obra e suas próprias experiências:

In diesem Buch [Das Leben geht weiter, U.W.] habe ich die Geschichte vom wirtschaftlichen Niedergang eines kleinen Selbstäntigen, meines Vaters, erzählt, die Vernichtung einer Existenz, zutiefst verknüpft mit den Wirren der Nachkriegszeit. Es war auch meine Geschichte. [...] Jetzt erst wurde mir bewusst, dass die damalige Selbstanalyse und die Beschreibung von Entwicklungen, soweit ich sie damals übersehen konnte, nur ein Teil der Selbstdarstellung waren. Den anderen, den des jungen Juden im damaligen Deutschland des aufkommenden Nationalsozialismus, schrieb ich erst in den Niederlanden mit dem Roman Der Tod des Widersachers, der in 1959 in Deutschland erschien. (WEYMANN 2013: 73) ${ }^{3}$

\footnotetext{
3 "Neste livro [Das Leben geht weiter] contei a história do declínio econômico de um pequeno autônomo meu pai -, a destruição de uma existência, profundamente ligada aos efeitos do pós-guerra. Era também minha história. [...] Apenas agora tomei consciência de que a autoanálise de então e descrição dos desenvolvimentos, tanto quanto pude relevá-los na época, eram apenas uma parte da autorrepresentação. A outra parte, do jovem judeu na Alemanha do nacional-socialismo emergente, escrevi primeiramente na Holanda com o romance A morte do inimigo, publicado na Alemanha em 1959."
} 
ANDRADE, P. - Ficcionalização do testemunho

Um levantamento mais detalhado poderia revelar outras confluências entre a biografia de Keilson e passagens de A morte do inimigo; mas a forte correspondência não basta para constituir a obra como autobiografia. Observe-se que o próprio Keilson se refere à obra como romance. Para Weymann, a forma está entre romance, ensaio e reflexão. Anna Parkinson (2013: 101) também aponta para a relação próxima entre os ensaios de Hans Keilson e seus romances. Ainda assim, sabemos que grande parte de uma obra ficcional é constituída por referências ao mundo real. O princípio de minimal departure, assim chamado por Marie-Laure Ryan, estabelece que a leitura de uma obra de ficção deve se afastar da representação do real o mínimo possível para permitir a criação da ficção em si - do elemento inventado. Asserção semelhante fez Frank Zipfel (2001: 86), chamando-a de "Realitätsprinzip", e também Umberto Eco (2002) já comentara que o mundo da ficção segue as mesmas leis e reproduz em grande parte as relações e elementos do mundo real.

Na obra em questão, em que não se nomeia o protagonista, temos um caso especialmente ambíguo quanto ao modo de leitura:

Ein eindeutiges Fiktionssignal homodiegetischer Erzählungen ist die beschriebene NichtIdentität des Autor-Namens mit dem Erzähler-Namen. Man findet jedoch auch homodiegetische Erzählungen ohne Nennung des Namens der Erzählerfigur. Bei solchen Erzählungen entfällt der Namensvergleich als Grundlage der Entscheidung, ob der Text als fiktional oder faktual anzusehen ist. Derartige Texte, wie z.B. Marguerite Duras' L'amant, scheinen es aber gerade darauf anzulegen, den Status des Textes in der Schwebe zu halten und damit dem Leser sowohl eine fiktionale wie auch eine faktuale Lesart zu ermöglichen. (ZIPFEL 2001: 141)

Enquanto o elemento paratextual identifica A morte do inimigo como romance, sua estrutura narrativa nos faz lê-lo como o caso especial e ambíguo de que comenta Zipfel. A mesma indeterminação é sugerida por Philippe Lejeune ao definir o que chama de pacto zero entre autor e leitor: "Não apenas o personagem não tem nome, mas o autor não firma nenhum pacto. A indeterminação é total. [...] O leitor, segundo seu humor, poderá ler essa narrativa no registro que quiser" (LEJEUNE 2014: 35). Passamos, portanto, à nossa primeira pergunta: qual o tipo de leitura a obra de Keilson engendra? Se o autor vivenciou, de fato, tantas das experiências que compõem Der Tod, que elementos o

\footnotetext{
4 “Um sinal ficcional característico das narrativas homodiegéticas é a [já] descrita não identificação do nome do autor com o nome do narrador. Entretanto, há também narrativas homodiegéticas que não nomeiam o narrador. Nessas narrativas, a comparação de nomes não serve de base para decidir se o texto deve ser considerado ficcional ou factual. Tais textos, como, por exemplo, L'Amant, de Marguerite Duras, parecem se concentrar em manter o status do texto em suspenso e, assim, permitir ao leitor tanto uma leitura ficcional como factual."
} 
ANDRADE, P. - Ficcionalização do testemunho

afastam da escrita autobiográfica que comumente marca a chamada literatura de Testemunho, e da qual demos Primo Levi como exemplo?

Para Stephan Braese (2010), trata-se de um "testemunho dissidente". Podemos considerá-lo testemunho na medida em que "transmite uma perspectiva subjetiva" (GALLE 2018a: 178) sobre o nacional-socialismo; contudo, não se trata de um testemunho do genocídio dos campos de concentração, como comumente é tematizado nas obras testemunhais. Este aparece de forma secundária na obra de Keilson, nos capítulos em que o narrador relata o triste destino de seus pais e seu sentimento de impotência perante esse destino. O mesmo é constituído de forma altamente poética a partir da figura da mochila que o pai do narrador-protagonista havia deixado preparada para o caso - ou melhor, para quando viessem buscá-los. Dentro da mochila, diversos itens de uma sociedade civilizada, como um livro, sabonetes e toalha - seriam levados para o lugar onde se destituía cada um de sua humanidade. Quanto à biografia do autor, sabe-se que seus pais foram mortos em Auschwitz. O testemunho que se presta, contudo, é dissidente, pois não trata dos campos de concentração, como em geral se encontra na assim chamada Literatura de Testemunho: a perspectiva subjetiva oferecida é sobre outros aspectos do acontecimento histórico que foi o nazismo, como a figura de um líder essencial ao movimento, a ameaça que pairava sobre judeus com a crescente popularização de suas ideias, os sentimentos do jovem que cresceu em meio ao fortalecimento dessas ideias, a impossibilidade de permanecer neutro em meio a esse cenário.

Apesar desses citados e de tantos outros elementos verificáveis na realidade, a atenta leitura da obra afasta-a cada vez mais de uma autobiografia, e aproxima-a da definição de romance autobiográfico, como postulou Philippe Lejeune:

Chamo assim todos os textos de ficção em que o leitor pode ter razões de suspeitar, a partir das semelhanças que acredita ver, que haja identidade entre autor e personagem, mas que o autor escolheu negar essa identidade ou, pelo menos, não afirmá-la. (LEJEUNE 2014: 29)

Para confirmar a suposição de que a leitura mais plausível da obra é a de um romance autobiográfico, passamos a destacar os elementos que nos fazem ler a obra como ficção: Fiktionssignale, para Frank Zipfel, ou índices de ficcionalidade, conforme tradução da obra de Genette. 


\section{3 Índices de ficcionalidade em $A$ morte do inimigo}

Um primeiro aspecto ficcional do romance se revela em suas primeiras e últimas páginas: inicia-se a narração em primeira pessoa, com o narrador explicando a origem do texto que vem a seguir, e que constitui a maior parte do romance. Sobre essa moldura extradiegética, podemos considerá-la como uma primeira marca de ficção, além de iniciar a problematização da autoria. O narrador relata ter recebido um pacote com o manuscrito (que constitui a narrativa intradiegética) de um advogado holandês, o qual, por sua vez, o teria recebido de um cliente, "um homem de trinta e poucos anos que às vezes o consultava sobre inócuos assuntos comerciais" (KEILSON 2013: 7) e que pouco depois desaparecera temporariamente em busca de segurança. O manuscrito estava em alemão, e o fato de seu autor ter procurado refúgio e ser perseguido, além de outras referências à ocupação e ao fim da guerra sugerem que seu autor seria um alemão que fugira da perseguição nazista e se asilara na Holanda, envolvendo-se em atividades clandestinas de falsificação. Aproxima-se, portanto, da figura de Keilson e afasta-se do mesmo ao narrar que o suposto autor trouxera seus pais para viver ali também (como já mencionamos, os pais de Hans Keilson foram mortos em Auschwitz-Birkenau). Assim, a figura do autornarrador-personagem da narrativa intradiegética em muito corresponde a Keilson, mas ainda traz a ressalva de um elemento ficcional que nos impede de vê-la como autobiografia.

Quanto ao relato extradiegético, constitui-se em grande parte do diálogo entre o narrador em primeira pessoa, que nos apresenta o manuscrito, e o advogado que o entregara. Neste diálogo, destacamos a incerteza que se estabelece com relação à autoria do manuscrito na parte que abre o romance:

Comecei a indagar sobre o autor, mas não obtive resposta. Sabia que o advogado falava alemão com fluência, e cheguei a desconfiar que o texto fosse dele. Fiz perguntas cautelosas. Ele riu e se limitou a dizer: "Leia se quiser". (KEILSON 2013: 8)

$\mathrm{Na}$ segunda parte da narrativa extradiegética, que fecha o romance, o narrador e o advogado conversam mais sobre o manuscrito e seu suposto autor:

"Por que ele não veio buscar suas notas depois da guerra?", perguntei. O advogado deu de ombros. Continuou a fumar.

"Eu não entendo", prossegui.

"Muitos não vieram buscar suas coisas quando a guerra acabou."

"É diferente."

"Você acha que ele ainda está vivo?"

"Foi ele que disse isso, descreveu a morte de seu inimigo."

$\mathrm{O}$ advogado pensou um pouco, olhou-me nos olhos e mordeu o lábio inferior. 
"Ele morreu", disse. [...]

"Mas e as coisas que escreveu?"

"Fantasia", revisou ele laconicamente. (KEILSON 2013: 254)

Eva-Maria Konrad (2015: 7), ao comentar o que chama de "ficção editorial", afirma que não é a existência do autor-editor (neste caso, o narrador da narrativa extradiegética) que é inventada, mas sim sua função. Diferentemente de Genette, que considera a ficção editorial como um paratexto, Konrad toma o prefácio como parte da ficção. Ao declarar a morte prematura do autor do manuscrito em confronto com um oficial, o narrador extradiegético assume a função de ficcionalizar o texto intradiegético; assim, sutilmente se estabelece, por meio da moldura extradiegética, um pacto romanesco. Podemos ratificá-lo listando outros Fiktionssignale presentes na narrativa intradiegética.

O capítulo 10 traz a narração de uma cena em que o protagonista e sua namorada estavam no apartamento dela quando chegaram seu irmão e alguns amigos. Embora nesse ponto da narrativa o narrador não se lembrasse do nome da namorada, o que se segue são 50 páginas de um diálogo entre os personagens, em que os amigos e o irmão da moça descrevem, ainda que meio hesitantes, a ocasião em que vandalizaram um cemitério judeu. Enquanto o esquecimento do nome da namorada confere verossimilhança à narrativa autobiográfica, como lacuna da memória, o relato da cena é feito em minúcias de detalhes:

"Já tínhamos recebido as passagens", disse o mais novo. "De modo que fomos para L., ninguém se conhecia, nem na estação nem no trem, isso eu percebi pela maneira como eles olhavam para mim. A viagem durou mais ou menos uma hora e meia, e, quando chegamos a L., estava anoitecendo. [...] E, assim, seguimos pelas ruas, lá onde o bosque sobe o morro e chega até as primeiras casas. Entramos numa trilha que envereda pela floresta e dá numa torre de vigia" (KEILSON 2013: 178).

Além dos detalhes da própria empreitada fúnebre são também detalhados gestos e disposições relativas ao próprio diálogo entre personagens: pausas, risos intercalados, expressões faciais e entonações. Para Käte Hamburger (apud GENETTE 1995: 761), a presença de cenas detalhadas e de diálogos reportados extensos pode ser incluída entre os índices de ficcionalidade; embora não seja absolutamente proibida na narrativa histórica ou memorialista, transgride sua verossimilhança, pois exigiria uma memória excessivamente prodigiosa. Além da cena que compõe o capítulo 10, há muitos outros diálogos reportados, extensos no romance (KEILSON 2013: 17, 32, 91). Embora não se valha do discurso indireto livre, a narrativa é rica em longas cenas e reprodução de longos diálogos, o que também costuma ser associado à ficção (ZIPFEL 2014: 110). 
ANDRADE, P. - Ficcionalização do testemunho

De forma semelhante e pelas mesmas razões acima mencionadas, as descrições extensas também são marcas da escrita ficcional. Dentre outras presentes na obra, há a descrição da loja de departamentos onde o protagonista trabalhou durante um certo período. Ocupando várias páginas do capítulo cinco, a descrição inclui detalhes arquitetônicos do prédio em que se situava a loja, a disposição dos departamentos em seu interior, os produtos que lá podiam ser encontrados, impressões e fragrâncias que se sentiam.

Mas na loja, embaixo, na rua por onde passavam os transeuntes, estendia-se uma fileira de amplas vitrines [...] e ao longo do centro da fachada, como se tivessem sido colados, pendiam os multicoloridos anúncios que chegavam à altura do portal [...]. E então você entra num salão alto, cuja iluminação vem da claraboia lá em cima. O salão se afunda à direita e à esquerda feito dois braços abertos para recebê-lo. [...] você sente no ar uma leve aragem, um cheiro de folhas de pinheiro, de sabonete, de perfumes e de talco, de pentes, bolsas e cachecóis. (KEILSON 2013: 82-83)

A descrição ainda se estende longamente mesclando percepções objetivas e subjetivas. O narrador situa seu leitor naquele universo de beleza e desejo que era a loja, ao mesmo tempo que resgata suas próprias sensações naquele ambiente, utilizando-se da narrativa no tempo presente. Dessa forma, o leitor é conduzido a uma espécie de experiência de visitação à loja por meio da memória e das impressões do narrador, criando-se uma ilusão de simultaneidade. A abundância das impressões, contudo, faz-nos duvidar de que o relato se baseie apenas na memória: certamente a experiência trazida por esta foi aí ficcionalizada.

Uma das marcas ficcionais mais evidentes diz respeito ao conhecimento do narrador: verbos de processos interiores [innere Vorgänge], monólogos interiores e diferentes focalizações são expedientes descritos pela narratologia que Zipfel (2001: 112) destaca como paradigmáticos da escrita ficcional. Observemos alguns exemplos presentes no romance de Keilson.

No capítulo dois, o narrador e sua mãe conversam sobre o pai, suas várias atividades profissionais ao longo da vida e seus insucessos. Ao relembrarem uma ocasião em que o pai fora traído pelo funcionário de um hotel onde trabalhava, lemos: “"Ele é bom demais e confiante demais', disse a mãe, exalando um suspiro. Essa afirmação livrou-a de um fardo que trazia nas costas havia anos" (KeIlson 2013: 31). Nota-se, portanto, que o narrador revela o sentimento da mãe, acessando seus sentimentos atrelados ao assunto do diálogo reportado. 
ANDRADE, P. - Ficcionalização do testemunho

Em outra passagem, o protagonista vinha sendo excluído dos jogos de futebol e do convívio em geral com os outros garotos, por ser "diferente" deles (judeu, sugere a interpretação). Sua mãe então vai com ele até o campo conversar com os meninos, e lemos: "A maioria dos garotos escutou com medrosa tensão. As poucas e serenas palavras de minha mãe os surpreenderam, já que esperavam coisa diferente, um sermão ou uma ameaça" (ibidem: 55). Neste trecho, o processo interno ao qual o narrador nos dá acesso é a expectativa e a surpresa dos outros garotos diante da situação. Assim, nessas situações em que a narrativa de processos internos alheios nos faz questionar "como o narrador poderia saber disso?", temos outra distinta marca de ficcionalidade.

Embora não esteja listada entre as marcas de ficcionalidade de Genette ou Zipfel, uma característica de $A$ morte do inimigo que se destaca ao leitor como primeiro índice de afastamento de uma escrita factual é a troca ou ocultação de nomes próprios. Como já comentamos, não se dá a saber o nome do protagonista-narrador; além disso, desconhecemos os nomes das cidades em que se desenvolve a história; e a condição de judeu do narrador, de sua família e alguns conhecidos não é explicitamente declarada: essa informação fica subentendida, suspensa na frase inacabada do pai ao tentar explicar para o narrador o porquê de terem aquele inimigo.

Quanto à figura do inimigo, do mesmo modo tem o nome ocultado. Chamado apenas de B., é um líder político que ascende durante a infância e adolescência do narrador, sendo admirado por muitos (como vários colegas do protagonista) e temido por tantos outros. É visto como um perigo para um certo grupo da sociedade - sobre o qual, por sua vez, também não se verbaliza serem judeus. Seus atributos, contexto e trajetória sugerem ao leitor uma nítida associação à figura de Hitler; por que, então, ocultar seu nome?

Segundo a verossimilhança interna do romance, o texto seria um manuscrito entregue ao narrador por um advogado holandês depois de ficar por anos enterrado em um quintal - como já comentamos ao analisar a moldura extradiegética do romance. A ocultação dos nomes seria, portanto, para proteger quem quer que estivesse de posse do manuscrito, já que não se configura dessa forma, explicitamente, um documento antinazista.

Outra marca ficcional bastante evidente é o desfecho da história. Enquanto Keilson fugiu para a Holanda, viveu meses escondido na casa de um casal holandês em Delft, envolveu-se na resistência e no apoio às vítimas do nazismo, atuou como terapeuta 
ANDRADE, P. - Ficcionalização do testemunho

e mais tarde como médico, e viveu até 2011, o narrador da história, segundo o advogado da narrativa extradiegética, morre em um confronto com um oficial nazista. A narrativa externa do advogado que recebe o manuscrito do livro esclarece que, em um inesperado encontro, o narrador e o oficial se alvejam e se matam mutuamente. Neste ponto podemos trazer de volta a questão da biografia ficcionalizada: assumidas as correspondências entre a vida de Keilson e seu personagem, qual seria o motivo desse desfecho inventado?

\section{Efeitos da ficcionalização}

Primo Levi, ao tratar das testemunhas dos campos de concentração, faz uma afirmação que pode ser ampliada de forma a abranger a condição dos perseguidos pelo nazismo de modo geral:

não somos nós, os sobreviventes, as autênticas testemunhas. Quem [tocou o fundo], quem fitou a górgona, não voltou para contar, ou voltou mudo. [...] são eles as testemunhas integrais, cujo depoimento teria significado geral. Eles são a regra, nós a exceção. Nós, tocados pela sorte, tentamos narrar com maior ou menos sabedoria não só o nosso destino, mas também aquele dos outros, dos que submergiram: mas tem sido [...] a narração de coisas vistas de perto, não experimentadas pessoalmente. [...] Falamos nós em lugar deles, por delegação. (apud AGAMBEN 2008: 42-43)

Do mesmo modo que Levi e outros sobreviventes dos campos de concentração relatam e testemunham em favor dos muitos que sucumbiram, o narrador-protagonista do romance de Keilson (que logrou sobreviver através do exílio) se torna porta-voz dos que foram vítimas da perseguição nazista e não viveram para testemunhar. A experiência da qual é dado testemunho, diferentemente do maior contingente das obras desse teor pósHolocausto, não é a dos campos de concentração e a luta diária pela sobrevivência; tratase da formação de um indivíduo sob a sombra da discriminação e da perseguição, centradas na figura de um poderoso inimigo. Expressa-se a busca por compreender a natureza do ódio, e a necessidade de ocultar-se; mostra-se, ainda, a fatalidade do confronto com os oficiais do poder vigente, em uma época em que muitas vidas se perderam em encontros fortuitos como o que causou a morte do narrador, ao confrontar um oficial.

Como podemos observar, traços estruturais ou sintáticos do texto apontam diversos índices de ficcionalidade. Ainda que não seja possível definir um gênero "puro" baseando-se na sintaxe (SCHAEFFER 2012), é possível decidir-se, enquanto leitor, pela leitura de A morte do inimigo como romance autobiográfico e, portanto, ficção. Passamos, 
ANDRADE, P. - Ficcionalização do testemunho

então, ao próximo questionamento: quais as consequências e possível intencionalidade de se escolher a ficção para relatar acontecimentos tão contundentemente próximos da experiência daqueles que conviveram com o nacional-socialismo?

Eurídice Figueiredo, em sua obra A literatura como arquivo da ditadura, cita Jacques Rancière ao dizer que "só a literatura é capaz de recriar o ambiente de terror vivido por personagens afetados diretamente pela arbitrariedade da tortura, pela humilhação, pois, como diz Jacques Rancière, o real precisa ser ficcionado para ser pensado" (FIGUEIREDO 2017: 43).

Se os romances têm a capacidade de aproximar leitores de experiências que eles não teriam de outro modo, compreendemos a afirmação de Rancière citada por Figueiredo como o ensejo da literatura de apresentar e problematizar a realidade. Assim posto, o propósito da obra ficcional não é fantasiar a partir de temas tão críticos como a perseguição, a necessidade do exílio, o genocídio. Fatos e dados foram continuamente revelados por estudos documentais nas décadas posteriores à Segunda Guerra. Ainda falta compreender, entretanto, "o sentido e as razões do comportamento de carrascos e das vítimas" (AGAMBEN 2008: 19), e para esse inesgotável propósito, a obra de Hans Keilson serve magistralmente, explorando a formação do jovem sob a ameaça e, posteriormente, sob o antissemitismo institucionalizado. O romance aprofunda a reflexão sobre a constituição dialética do eu como contraparte do inimigo, sobre a natureza do ódio, e, no caso do protagonista de A morte do inimigo, sobre a resistência à própria atitude de resistência, sendo vencida pela necessidade de se posicionar, forçada pelo exílio.

Ao comentar o papel da moralidade na ficção de diferentes épocas, Bunia (2018: 97) afirma que uma das principais aplicações da ficção moderna era a discussão moral do comportamento humano. Na mesma direção, Walton (2018: 286) sugere que "obras talvez sirvam menos como veículos para argumentos 'factuais' e mais para argumentos morais". Para que uma obra que retrate qualquer aspecto do nacional-socialismo tenha impacto sobre o leitor - e possa, inclusive, influenciar sua formação moral (GALLE 2018b: 31) -, não é necessário que seja comprovadamente autobiográfica. A elaboração estética, como argumenta Figueiredo, não enfraquece a contundência do relato ou das reflexões trazidas pelo romance, mas, ao invés disso, pode torná-las mais compreensíveis ao leitor.

Helmut Grugger (2013) destaca a oscilação entre primeira e terceira pessoa no texto, assim como o uso alternado de "Du" e "man", e interpreta a alternância entre 
pronomes como a possibilidade de se ler os eventos narrados para além da instância particular:

Das fiktive "Du" dient hier wieder der intersubjektiven Anbindung an aussen, es wird Teil der vielen Perspektiven von Außenbeobachter, figuraler Perspektive des Vaters und der Mutter, kindlichem und reflektierendem Ich sowie dessen Referenz auf das Allgemeine, welche durch das „Du” symbolisiert wird; Die traumatische Erfahrung wird als eine potentiell allgemeine codiert, welche doch als einzigartig detailliert entfaltet wird, aber sich in dieser Singularität auch anders ereignen könnte. Keilson fiktionalisiert also die Gleichzeitigkeit von singulärer Nicht-Identität und über das Individuum hinausgreifenden Aspekten des Traumas. (GRUGGER 2013: 150) ${ }^{5}$

A história de A morte do inimigo, portanto, ficcionalizada, pode ser lida não apenas como experiência traumática de um indivíduo, história particular de uma autobiografia, mas sim como experiência de muitos outros, dilemas compartilhados por tantos quantos vivenciaram o surgimento - e em muitos casos também o enfrentamento - de um inimigo.

\section{Considerações finais}

Embora não se possa determinar um gênero literário com base apenas em aspectos textuais, o acúmulo de marcas de ficcionalidade tende a sugerir a leitura de uma obra como ficcional, em casos ambíguos em que não há o estabelecimento claro de um pacto autobiográfico ou ficcional. Tais marcas, em grande parte sintáticas e estilísticas, apontam para a elaboração estética enquanto expediente da escrita em primeira pessoa. Esta, contudo, não diminui a contundência do relato: pelo contrário, torna-o mais compreensível ao leitor e conduze-o por experiências que, de outro modo, não poderia vivenciar.

O romance A morte do inimigo, de Hans Keilson, possui características de uma obra de pacto testemunhal (GALLE 2018a: 173): transcende-se a fronteira discursiva entre ficção e não ficção, pois "os livros de sobreviventes rotulados como romances não precisam apresentar comentários sobre sua fidelidade aos fatos históricos para que o público perceba a sinceridade dos relatos" (idem 2018: 175). A obra possui diversos

\footnotetext{
5 ' $\mathrm{O}$ 'tu' fictício serve como conexão intersubjetiva com o exterior, torna-se parte das muitas perspectivas do observador externo, da perspectiva figurativa do pai e da mãe, do eu infantil e reflexivo, bem como de sua referência ao geral, que é simbolizado pelo "du"; a experiência traumática é codificada como uma experiência potencialmente geral, a qual é desdobrada como singularmente detalhada, mas também poderia ocorrer de outra forma nessa singularidade. Keilson ficcionaliza, portanto, a simultaneidade da nãoidentidade singular e os aspectos do trauma além do indivíduo."
} 
ANDRADE, P. - Ficcionalização do testemunho

elementos referenciais e verificáveis na biografia do autor, entretanto a inserção desse texto enquadrado em outra narrativa secundária, seu desfecho e um considerável número de índices de ficcionalidade que procuramos apontar reforçam a sugestão à leitura do texto como romance autobiográfico e, portanto, ficção.

Ainda assim, a obra suscita profundas reflexões acerca da natureza do ódio, da constituição mútua entre perseguido e perseguidor, da necessidade de se posicionar e agir diante da perseguição, e da relação com o inimigo, posto aqui como principal razão para desventuras na vida do narrador e tantos outros. Se não é relato que possa ser tido como documental, a estetização do escrito não diminui a força de seu impacto no leitor, enquanto problematiza várias questões psicológica e humanamente profundas relativas ao nacional-socialismo.

A escolha de narrar experiências próprias e de postular reflexões bastante subjetivas em forma de ficção amplia o alcance da obra. À semelhança da mímese aristotélica, a ficção trata daquilo que poderia vir a acontecer a qualquer um. A leitura empática dos sofrimentos e pensamentos do protagonista-narrador homodiegético coloca o romance de Keilson em especial posição dentro do escopo da literatura sobre a Shoah.

\section{Referências bibliográficas}

Agamben, G. O que resta de Auschwitz. São Paulo: Boitempo, 2008.

BRAESE, S. "Dissidente Zeugenschaft: hans Keilson's Der Tod des Widersachers im Kontext der deutschsprachigen Nachkriegsliteratur". In: VOGEL-KLEIN, R. (org.). Die ersten Stimmen: deutschsprachige texte zur Shoah 1945-1963. Würzburg: Königshausen \& Neumann, 2010. p. 33-48.

BUNIA, R. "Uma história moral da ficção". In: GALle, H. P. E. PeREZ, J. P.; PEREIRA, V. S. (org.). Ficcionalidade: uma prática cultural e seus contextos. São Paulo: FFLCH/USP: Fapesp, 2018. p. 95-110

ECO, U. Seis passeios pelos bosques da ficção. 1. ed. São Paulo: Companhia das Letras, 2002.

FIGUEIREDO, E. A literatura como arquivo da ditadura brasileira. Rio de Janeiro: 7Letras, 2017.

GALle, H. "O testemunho: um novo paradigma da ficção?" In: GALle, Helmut P. E. PEREZ, Juliana P.; PEREIRA, Valéria S. (org.). Ficcionalidade: uma prática cultural e seus contextos. São Paulo: FFLCH/USP: Fapesp, 2018a. p. 167-186.

GALLE, H. "Pequena introdução à teoria da ficcionalidade seguida por uma bibliografia". In: Galle, Helmut P. E.; Perez, J. P.; Pereira, V. S. (org.). Ficcionalidade: uma prática cultural e seus contextos. São Paulo: FFLCH/USP: Fapesp, 2018b. p. 17-45.

GENETTE, G. Discurso da narrativa. Lisboa: Veja, 1995.

GRUGGER, H. “'Schrei ins Leere': Hans Keilsons Poetik der Intersubjektivität zwischen Sagbaren und Unsagbaren". In: SCHRÖDER, S.; WeYMANN, U.; WidMANN, A. (org.). "Die vergangene Zeit bleibt die erlittene Zeit": untersuchungen zum Werk von Hans Keilson. Würzburg: Königshausen \& Neumann, 2013. p. 145-158.

Pandaemonium, São Paulo, v. 22, n. 38, set.-dez. 2019, p. 168-182 
ANDRADE, P. - Ficcionalização do testemunho

KeILson, H. A morte do inimigo. Tradução de Luiz A. de Araújo. São Paulo: Companhia das Letras, 2013.

KONRAD, E. M. “"The Poet, he nothing affirms, and therefore never lieth'? An analysis of editorial fiction". Diegesis, Wuppertal, v. 4, n. 1, 2015, p. 1-17.

LEJEUNE, P. O pacto autobiográfico: de Rousseau à internet. Belo Horizonte: Editora UFMG, 2014.

LEVI, P. É isto um homem? Tradução de Luigi Del Re. Rio de Janeiro: Rocco, 1988.

PARKINSON, A. "Death of the adversary: enduring ambivalece in Hans Keilson's postwar psychoanalytic literature". In: SCHRÖDER, S.; WEYMANN, U.; WIDMANN, A. (org.). "Die vergangene Zeit bleibt die erlittene Zeit": untersuchungen zum Werk von Hans Keilson. Würzburg: Königshausen \& Neumann, 2013. p. 91-103.

RYAN, M. L. Fiction, non-factuals, and the principle of minimal departure. Poetics, Amsterdam, v. 9 , n. 4, 1980, p. 403-422.

SCHAEFFER, J. M. "Fictional vs. Factual Narration". In: HÜHN, P. et al. (ed.): The living handbook of narratology. Hamburg: Hamburg University, 2012. Disponível em: http://www.lhn.uni-hamburg.de/article/fictional-vs-factual-narration. Acesso em: 17 jan. 2019.

WALton, K. "Moral na ficção e moralidade ficcional". In: GALLE, H. P. E.; PEREZ, J.P.; PeREIRA, V. S. (org.). Ficcionalidade: uma prática cultural e seus contextos. São Paulo: FFLCH/USP: Fapesp, 2018. p. 289-312.

WEYMANN, U. "Erinnerung und Wirklichkeitsverlust in Der Tod des Widersachers". In: SCHRÖDER, S.; WEYMANN, U.; WIDMANN, A. (org.). "Die vergangene Zeit bleibt die erlittene Zeit”: untersuchungen zum Werk von Hans Keilson. Würzburg: Königshausen \& Neumann, 2013. p. 71-89.

ZIPFEL, F. Fiktion, Fiktivität, Fiktionalität: analysen zur Fiktion in der Literatur und zum Fiktionsbegriff in der Literaturwissenschaft. Berlin: Erich Schmidt, 2001.

ZIPFEL, F. "Fiktionssignale". In: KÖPPE, T.; KLAUK, T. (ed.), Fiktionalität: ein interdisziplinäres Handbuch. Berlim: De Gruyter, 2014. p. 97-124. 